\title{
Student Background: An Invaluable Player for Academic Success
}

\author{
Sarnesh Deo \\ School of Computing, Information \\ and Mathematical Sciences \\ The University of South Pacific \\ Suva, Fiji \\ sarneshd@gmail.com
}

\author{
Kaylash Chaudhary \\ School of Computing, Information \\ and Mathematical Sciences \\ The University of South Pacific \\ Suva, Fiji \\ kaylash.chaudhary@usp.ac.fj
}

\author{
Bibhya Sharma \\ School of Computing, Information \\ and Mathematical Sciences \\ The University of South Pacific \\ Suva, Fiji \\ bibhya.sharma@usp.ac.fj
}

\begin{abstract}
Student background undoubtedly influences the performance of students in computer science. The literature verily indicates that there are many key aspects of student background that influence students' performance in a programming course. These include the socioeconomic status, demographic profile, types of gadgets students have, home possessions, and internet connectivity. This study aims to find answers to some pertinent questions related to different aspects of background and their association with computer science students' performance. A questionnaire-based survey was used to collect data for analysis from a first-year computer programming course at a regional university in the South Pacific. This paper presents the students' demographic and socioeconomic profiles and investigates their association with students' performance. The results show that a student's background is a significant factor in influencing their computing course performance.
\end{abstract}

Keywords- Socioeconomic status, PISA study, home possessions, educational performance

\section{INTRODUCTION}

Education is essential in society because society and education are inter-dependent. On the one hand, a child's nature and development in society are governed by his/her education. On the other hand, society influences the processes, changes and progress of education. The school is a parent body governing children from different parental backgrounds and social background. Student academic performance assessment has received considerable attention in the past few years, and their performance is affected due to psychological, socioeconomic and personal factors [21]. The student's school performance is determined by the factors in which the child finds him or herself. These factors include socioeconomic, psychological, cultural, genetic, environmental, and emotional [17]. These factors strongly influence student performance, but these factors may vary from person to person and country to country [21].

Families with better socioeconomic status often have more success in preparing their children for school because they can afford a wide range of resources to help students develop. They can provide them with useful household items, books, computers, laptops, mobile phones, and internet access to encourage students in various learning activities at home [17].

After a comprehensive review of the literature, it was found that the failure rate in computing courses is not only a local challenge at our institution but rather universal $[22,23]$. Nikula reported that more than $30 \%$ of computer science (CS) students worldwide in 1999 dropped or failed the introductory programming course $[26,27]$. Corney et al. linked failure in introductory programming courses to degree withdrawal [22]. These high dropouts and failure rates should be a big concern for universities, instructors, and students. Students need to pass the introductory gateway course, a pre-requisite for all other CS courses and other disciplines, and failure in the course can delay graduation [23].

The literature states that there is a significant correlation between students' performance in university courses and socioeconomic factors such as household items, computers, laptops, smartphones, and access to the internet. There is a dearth of relevant research conducted on the relationship between a student's socioeconomic status and computer programming performance in the South Pacific.

The paper's objective is to see the effect of students background on their performance in a first-year programming course. This research will be helpful to all the universities, parents, instructors and students to guide them correctly and as per their abilities. The universities and instructors will be able to transform the course to best suit students from all SES. Parents will be encouraged to buy and involve in the learning materials for the students to use at home to help them succeed.

The paper starts by looking at various literature and find the trends in international universities about the student background and its effect on their performance. The next section analyses the data about students' background and reported in frequency distribution tables to find a correlation with their performance. The paper provides an overview of these factors and students' performance in a computing programming course.

\section{RELATED WORKS}

Socioeconomic status (SES) is measured as a combination of education, income, and occupation [2]. It is conceptualised as the social standing or class of an individual or group. Research indicates that children from low SES households and communities develop academic skills more slowly than children from higher SES groups [14-19]. The family and the household are the first social system where students begin to acquire the fundamental cognitive and social skills necessary for school and life $[3,20]$. The material resources available in the household where students live can influence their cognitive and psychological development, but some resources matter more than others [3].

Programme for International Student Assessment (PISA) consistently finds that socioeconomic status is connected with performance at the system, school, and student levels. PISA reported that one of the home possessions that most clearly differentiates students of different socioeconomic backgrounds is the number of books at home. While $47 \%$ of advantaged students reported having more than 200 books at home, on average, this is the case for only $7 \%$ of 
disadvantaged peers. Advantaged students also reported greater availability of other educational resources, such as educational software. However, on average, across Organisation for Economic Co-operation and Development (OECD) countries, more than $80 \%$ of students, regardless of their socioeconomic status, reported having a quiet place to study at home and a computer they can use for schoolwork [4].

Living in a home where children have a quiet space to study or engage in other activities is particularly important for students' learning. Across OECD countries, around $92 \%$ of students reported having a desk to study at and a quiet place to concentrate. However, in Colombia, Indonesia, Mexico, Thailand, and Trinidad and Tobago, at least one in four students reported that they do not have a quiet place to study at home [20].

In China, $61 \%$ of students in advantaged schools have access to a room in their school where they can do their homework, while only $14 \%$ of students in disadvantaged schools have access to such a room. In Japan, $96 \%$ of students have access to a quiet place to study at school, and there is no difference in access between advantaged and disadvantaged schools[20].

Students reported that they have a quiet place to study in Belgium, France, Germany, and Luxembourg. In these countries, the students who reported that they do not have a quiet place to study are well below the OECD average of $8 \%$. These disadvantaged students probably suffer from other forms of material deprivation and benefit. PISA could not prove a causal relationship between a quiet place to study at home and academic performance. An analysis based on random variations in overcrowding (based on the fact that same-sex siblings are more likely to share a room) shows that the relationship between poor living conditions and academic failure is plausibly one of cause and effect (Goux and Maurin, 2005). The negative association between the availability of a quiet space for learning and academic achievement originates in early childhood and may build over time [20].

In a developing country, demographic location, home possessions, and resources at students' disposal are likely to affect their academic performance [20]. The school systems in low-SES communities are often under-resourced, negatively affecting students' academic progress [15-19]. In recent years, researchers have emphasised the significance of various home resources as indicators of family SES background $[6,8,17,18]$.

These resources include household possessions such as books, computers, a study room, and the availability of educational services in the school [4]. In the typical Organisation for Economic Co-operation and Development OECD country, on average, more than $90 \%$ of students enjoy a desk, a quiet place to study, a dictionary, an internet connection, and a DVD player at home. Classical literature and educational software are also relatively uncommon, followed by technical reference books and works of art [3].

Data collected from students participating in the PISA assessment show that, by 2015 , almost every student (95\%) in most OECD countries reported that they had a link to the internet at home. In Denmark, Estonia, Finland, Iceland, Norway, Slovenia, and Switzerland, almost all students had Internet access at home. In the lower-income countries of Algeria, Indonesia, Peru, and Vietnam, fewer than one in two students reported having Internet access at home [20].
In $2015,91 \%$ of students had access to a cell phone at home that was connected to the internet (smartphone), 74\% had access to a portable laptop, $60 \%$ had access to a desktop computer, and $53 \%$ had access to a tablet that was connected to the internet. In Australia, Austria, Belgium, Denmark, Iceland, Luxembourg, the Netherlands, and Portugal, more than $80 \%$ of students had access to a portable laptop or a notebook at home. In China, the Dominican Republic, and Peru, less than $40 \%$ of students had access to such devices. In Colombia, the Dominican Republic, Mexico, and Peru, only two in three students had access to a smartphone at home [20].

Yinusa and Basil found that the socioeconomic factors influencing students' academic performance in Nigeria were a major factor in the student's academic performance and development [24]. Farooq et al., in their study, showed factors affecting students' academic performance in Pakistan were due to family characteristics like socioeconomic status, which were significant predictors for their performance at schools [25].

Researchers globally found that socioeconomic status, parental involvement, and family size are particularly important factors [12]. The reviewed literature revealed that many studies were done on socioeconomic factors influencing academic performance globally. To date, Fiji and the South Pacific region have made no advancements in research in this area. Hence, a knowledge gap exists in the area of socioeconomic factors and student performance association. The proposed study seeks to fill the gaps by finding out the socioeconomic factors influencing student's academic performance at a regional university in the south pacific region.

\section{METHODOLOGY}

Universities all over the world strive to achieve quality education for their students. In order to accomplish this, many factors must be put into consideration. Among them is the student's socioeconomic background. The family has a significant role to play in students' overall performance and their educational upbringing.

The overall research problem addressed in this study is that despite universities putting much effort into improving the quality of education for their students and academic performance, there is still the issue of home background characteristics that have to be addressed. Therefore, this study was set out to examine students' home background characteristics and academic performance in a selected computer programming course at the University of the South Pacific (USP).

The University of the South Pacific (USP) is the premier tertiary education provider in the Pacific region. The computer programming course that was selected was CS111 Introduction to Computing Science. CS111 is a first-year level course taught to students from all the disciplines.

The data collected for the study was through a questionnaire which contained items regarding student background, demographic location, home possessions, ethnic roots, types of gadget, and internet connection.

Much of the instrument was adapted and customised from the PISA study [3]. The questionnaire was distributed to CS111 students in the early weeks of their semester. Students' backgrounds in the questionnaire were asked about their living status in the family, their language, household items they own, 
internet connectivity, and gadgets they own. The student's grades (GPA) were also recorded to measure their performance levels in the course.

All data were either binary or multi-categorical in nature for easy collection. For analysis purposes, the selected response items were re-coded to a numerical scale, which ranged from 1 to 5 . Negatively phrased items were reversed coded such that a high score reflected the most positive scale.

\section{RESULTS}

\section{A. Exploring Student Background}

One hundred thirty-two (132) students responded to the questionnaire and had completed the course for a grade.

The participants were asked various questions about their background in the questionnaire, where it required multiple responses. Most of the students' feedback helped understand how their background factors affected their computer programming course performances.

The first question in the questionnaire was about the living status of the students. It was asked whether students lived with their parents, uncle, aunt, cousin, grandparents, other university students, spouses, or children. Table I shows the students' responses, where $43.94 \%$ indicated that they live with their parents, which was the most popular choice.

The questionnaire also asked students about the availability of 14 household items at home that were seen as appropriate socioeconomic status measures. Three indices were derived from these items: i) home educational resources, ii) ICT resources, and iii) home possessions.

Table I describes the items students have in their homes, which helps them to study better. It is stated that most of the students have a desk in their homes which they use for their study and they own a computer. These are the two items the most popular possessions among the students.

\section{TABLE I. HOUSEHOLD ITEMS}

\begin{tabular}{|l|c|c|}
\hline \multirow{2}{*}{ Which of the following are in your home? } & \multicolumn{2}{|c|}{ Responses } \\
\cline { 2 - 3 } & $\boldsymbol{N}$ & Percent (\%) \\
\hline A desk to study at & 95 & 71.97 \\
\hline A room of your own & 76 & 57.58 \\
\hline A quiet place to study & 54 & 40.91 \\
\hline A computer you can use for your study & 94 & 71.21 \\
\hline Educational software & 39 & 29.55 \\
\hline A link to the Internet & 59 & 44.70 \\
\hline Books to help with your study & 51 & 38.63 \\
\hline Technical reference books or manuals & 17 & 12.88 \\
\hline A dictionary & 74 & 56.06 \\
\hline A dishwasher & 14 & 10.61 \\
\hline A DVD player & 67 & 50.76 \\
\hline A guest room & 23 & 17.42 \\
\hline A high-speed Internet connection & 26 & 19.70 \\
\hline A musical instrument & 36 & 27.27 \\
\hline
\end{tabular}

Students were asked about the types of the gadget (educational resource) they owned, which help them in their studies. The results showed that about $29 \%$ have a mobile phone that does not have internet, whereas about $25 \%$ have smartphones with the internet. About 35\% have a laptop, and approximately $6 \%$ have tablet computers and desktop computers.

Students were asked about the places where they access the internet the most. The answering format was a four-point
Likert scale with the answering categories "often", "sometimes", "once or twice", and "never". It was noted that the university computer labs were the most common place where students accessed the internet.

TABLE II. STUDENTS INTERNET ACCESS

\begin{tabular}{|c|c|c|c|c|}
\hline Responses & Often & Sometimes & $\begin{array}{c}\text { Once or } \\
\text { twice }\end{array}$ & Never \\
\hline $\begin{array}{l}\text { From the } \\
\text { internet at home }\end{array}$ & $\begin{array}{c}46 \\
(34.8 \%)\end{array}$ & $\begin{array}{c}46 \\
(34.8 \%)\end{array}$ & $\begin{array}{c}16 \\
(12.1 \%)\end{array}$ & $\begin{array}{c}24 \\
(18.2 \%)\end{array}$ \\
\hline $\begin{array}{l}\text { From an } \\
\text { internet cafe or } \\
\text { hotspot }\end{array}$ & $\begin{array}{c}9 \\
(6.8 \%)\end{array}$ & $\begin{array}{c}23 \\
(17.4 \%)\end{array}$ & $\begin{array}{c}40 \\
(30.3 \%)\end{array}$ & $\begin{array}{c}60 \\
(45.5 \%) \\
\end{array}$ \\
\hline $\begin{array}{l}\text { From a } \\
\text { computer lab at } \\
\text { the university }\end{array}$ & $\begin{array}{c}56 \\
(42.4 \%) \\
\end{array}$ & $\begin{array}{c}56 \\
(42.4 \%) \\
\end{array}$ & $\begin{array}{c}12 \\
(9.1 \%) \\
\end{array}$ & $\begin{array}{c}8 \\
(6.1 \%) \\
\end{array}$ \\
\hline $\begin{array}{l}\text { From the wireless } \\
\text { network on } \\
\text { campus }\end{array}$ & $\begin{array}{c}46 \\
(34.8 \%)\end{array}$ & $\begin{array}{c}34 \\
(25.8 \%)\end{array}$ & $\begin{array}{c}27 \\
(20.5 \%)\end{array}$ & $\begin{array}{c}25 \\
(18.9 \%)\end{array}$ \\
\hline $\begin{array}{l}\text { From a } \\
\text { smartphone }\end{array}$ & $\begin{array}{c}26 \\
(19.7 \%)\end{array}$ & $\begin{array}{c}30 \\
(22.7 \%)\end{array}$ & $\begin{array}{c}21 \\
(15.9 \%)\end{array}$ & $\begin{array}{c}55 \\
(41.7 \%)\end{array}$ \\
\hline
\end{tabular}

\section{B. Does student background affect their performance?}

While many disadvantaged students succeed at school, including those who achieve at high levels internationally, socioeconomic status is associated with significant performance differences in most countries. Advantaged students tend to outscore their disadvantaged peers by large margins, and other factors may also compound those differences in performance [20].

This section shows the student home background factors that influence their performance in the computing course. From Table III, it is observed in the data that $53 \%$ passed the course. It shows that the E graders were twice the number out of those that failed, compared to D-graders. Out of those that passed, $19 \%$ were $\mathrm{A}$ or $\mathrm{A}+$ students, $36 \%$ were $\mathrm{B}$ or $\mathrm{B}+$ students, while $45 \%$ were $\mathrm{C}$ or $\mathrm{C}+$ students. Table VI shows the student grade distribution in the computing course.

\section{TABLE III. STUDENT GRADE DISTRIBUTION}

\begin{tabular}{|c|c|c|}
\hline Grade & Frequency & Percent(\%) \\
\hline A + & 6 & 4.5 \\
\hline A & 7 & 5.3 \\
\hline B + & 11 & 8.3 \\
\hline B & 14 & 10.6 \\
\hline C + & 19 & 14.4 \\
\hline C & 13 & 9.8 \\
\hline D & 21 & 15.9 \\
\hline E & 41 & 31.1 \\
\hline
\end{tabular}

Apart from presenting the frequency tables, different hypotheses were tested to see if students' background affected the performance in any way. Multiple Response Analysis from SPSS software was carried out to investigate individual items' popularity in all the multiple response sets. Crosstabulations were drawn up to see the frequencies of each of those items in the groups. Chi-square tests of independence were conducted at a 5\% level of significance for each hypothesis to determine any significant associations between a particular background and academic performance. 


\section{Effects of Living Status on Performance}

Table IV reveals that about $73 \%$ of the students live with their parents, uncles, cousins, and other USP students. As far as their grade distributions are concerned, about $62 \%$ of those that live with their spouse or children pass the course. Another status of living presents an almost $50 \%$ chance of pass or failure. the following null and alternative hypotheses were set up to conduct the hypothesis test:

$$
\begin{gathered}
H_{0}: \text { Statistically no significant association } \\
H_{1}: \text { Statistically significant association }
\end{gathered}
$$

\begin{tabular}{|c|c|c|c|c|c|c|c|c|}
\hline \multirow{2}{*}{ Living Status } & \multicolumn{8}{|c|}{ Grades } \\
\hline & $A+$ & $A$ & $B+$ & $B$ & $C+$ & $C$ & $D$ & $E$ \\
\hline Living with my parents & $\begin{array}{c}2 \\
3.4 \% \\
\end{array}$ & $\begin{array}{c}5 \\
8.6 \%\end{array}$ & $\begin{array}{c}5 \\
8.6 \%\end{array}$ & $\begin{array}{c}7 \\
12.1 \%\end{array}$ & $\begin{array}{c}6 \\
10.3 \%\end{array}$ & $\begin{array}{c}7 \\
12.1 \%\end{array}$ & $\begin{array}{c}8 \\
13.8 \%\end{array}$ & $\begin{array}{c}18 \\
31.0 \%\end{array}$ \\
\hline Living with my uncle, aunt, cousin, or grandparents & $\begin{array}{c}2 \\
8.7 \%\end{array}$ & $\begin{array}{c}0 \\
0 \%\end{array}$ & $\begin{array}{c}1 \\
4.3 \%\end{array}$ & $\begin{array}{c}3 \\
13.0 \%\end{array}$ & $\begin{array}{c}3 \\
13.0 \%\end{array}$ & $\begin{array}{c}2 \\
8.7 \%\end{array}$ & $\begin{array}{c}4 \\
17.4 \%\end{array}$ & $\begin{array}{c}8 \\
34.8 \%\end{array}$ \\
\hline Living with my Spouse & $\begin{array}{c}0 \\
0 \% \\
\end{array}$ & $\begin{array}{c}1 \\
7.7 \%\end{array}$ & $\begin{array}{c}0 \\
0 \% \\
\end{array}$ & $\begin{array}{c}2 \\
15.4 \%\end{array}$ & $\begin{array}{c}2 \\
15.4 \%\end{array}$ & $\begin{array}{c}3 \\
23.1 \%\end{array}$ & $\begin{array}{c}2 \\
15.4 \%\end{array}$ & $\begin{array}{c}3 \\
23.1 \%\end{array}$ \\
\hline Living with my children & $\begin{array}{c}0 \\
0 \% \\
\end{array}$ & $\begin{array}{c}1 \\
9.1 \% \\
\end{array}$ & $\begin{array}{c}0 \\
0 \% \\
\end{array}$ & $\begin{array}{c}21 \\
8.2 \% \\
\end{array}$ & $\begin{array}{c}2 \\
18.2 \%\end{array}$ & $\begin{array}{c}2 \\
18.2 \%\end{array}$ & $\begin{array}{c}1 \\
9.1 \% \\
\end{array}$ & $\begin{array}{c}3 \\
27.3 \% \\
\end{array}$ \\
\hline Living with other USP students, who are not family. & $\begin{array}{c}1 \\
3.2 \% \\
\end{array}$ & $\begin{array}{c}1 \\
3.2 \% \\
\end{array}$ & $\begin{array}{c}3 \\
9.7 \% \\
\end{array}$ & $\begin{array}{c}3 \\
9.7 \% \\
\end{array}$ & $\begin{array}{c}7 \\
22.6 \% \\
\end{array}$ & $\begin{array}{c}3 \\
9.7 \% \\
\end{array}$ & $\begin{array}{c}5 \\
16.1 \% \\
\end{array}$ & $\begin{array}{c}8 \\
25.8 \% \\
\end{array}$ \\
\hline Living with others who are not USP students nor family & $\begin{array}{c}0 \\
0 \% \\
\end{array}$ & $\begin{array}{c}0 \\
0 \% \\
\end{array}$ & $\begin{array}{c}0 \\
0 \% \\
\end{array}$ & $\begin{array}{c}0 \\
0 \% \\
\end{array}$ & $\begin{array}{c}0 \\
0 \% \\
\end{array}$ & $\begin{array}{c}0 \\
0 \% \\
\end{array}$ & $\begin{array}{c}0 \\
0 \% \\
\end{array}$ & $\begin{array}{c}0 \\
0 \% \\
\end{array}$ \\
\hline Living alone & $\begin{array}{c}2 \\
13.3 \%\end{array}$ & $\begin{array}{c}1 \\
6.7 \% \\
\end{array}$ & $\begin{array}{c}1 \\
6.7 \% \\
\end{array}$ & $\begin{array}{c}0 \\
0 \% \\
\end{array}$ & $\begin{array}{c}4 \\
26.7 \% \\
\end{array}$ & $\begin{array}{c}0 \\
0 \% \\
\end{array}$ & $\begin{array}{c}3 \\
20 \% \\
\end{array}$ & $\begin{array}{c}4 \\
26.7 \% \\
\end{array}$ \\
\hline
\end{tabular}

TABLE IV. STUDENTS LIVING STATUS AND GRADE DISTRIBUTION

The chi-square test $\left(x^{2}=39.613\right)$ shows that there is statistically no significant association ( $p$-value $=0.828$; $\mathrm{df}=$ 49) between the living status and the students' performance. In other words, the data does not have any evidence that the living status of students would affect a pass or fail in the computing course.

\section{Effects of Home Possession on Performance}

The hypothesis was set up to test whether home possessions affect the students' performance in the course, as shown previously. Table $\mathrm{V}$ reveals that the most popular items the students had at their expense were a study desk, a computer, and a study room. These did not, however, have any significant association with their performance $\left(x^{2}=103.44\right.$, $\mathrm{df}=98, \mathrm{p}$-value $=0.334)$ in terms of achieving a particular grade. However, there is a statistically significant association $\left(x^{2}=30.569, \mathrm{df}=14, \mathrm{p}\right.$-value $\left.=0.006\right)$ between the home possessions and the pass or fail status of the student. The notable home possessions with a $60 \%$ pass rate and $40 \%$ failure are educational software, internet or high-speed connectivity, textbooks and reference books, a guest room, dishwasher, and musical instrument.

TABLE V. STUDENTS PERFORMANCE WITH HOUSEHOLD ITEMS

\begin{tabular}{|l|c|c|c|c|c|c|c|c|}
\hline \multirow{2}{*}{ Possessions } & \multicolumn{7}{|c|}{ GPA } \\
\cline { 2 - 8 } & $\boldsymbol{E}$ & $\boldsymbol{D}$ & $\boldsymbol{C}$ & $\boldsymbol{C}+$ & $\boldsymbol{B}$ & $\boldsymbol{B}+$ & $\boldsymbol{A}$ & $\boldsymbol{A}+$ \\
\hline A desk to study at & $30(31.6 \%)$ & $16(16.8 \%)$ & $10(10.5 \%)$ & $14(14.7 \%)$ & $10(10.5 \%)$ & $7(7.4 \%)$ & $4(4.2 \%)$ & $4(4.2 \%)$ \\
\hline A room of your own & $20(26.3 \%)$ & $14(18.4 \%)$ & $8(10.5 \%)$ & $9(11.8 \%)$ & $10(13.2 \%)$ & $7(9.2 \%)$ & $3(3.9 \%)$ & $5(6.6 \%)$ \\
\hline A quiet place to study & $14(25.9 \%)$ & $9(16.7 \%)$ & $6(11.1 \%)$ & $7(13 \%)$ & $7(13 \%)$ & $4(7.4 \%)$ & $3(5.6 \%)$ & $4(7.4 \%)$ \\
\hline A computer youcan use for your study & $25(26.6 \%)$ & $14(14.9 \%)$ & $10(10.6 \%)$ & $15(16 \%)$ & $11(11.7 \%)$ & $8(8.5 \%)$ & $7(7.4 \%)$ & $4(4.3 \%)$ \\
\hline Educational software & $8(20.5 \%)$ & $4(10.3 \%)$ & $3(7.7 \%)$ & $8(20.5 \%)$ & $7(17.9 \%)$ & $2(5.1 \%)$ & $4(10.3 \%)$ & $3(7.7 \%)$ \\
\hline A link to the Internet & $13(22 \%)$ & $10(16.9 \%)$ & $5(8.5 \%)$ & $8(13.6 \%)$ & $9(15.3 \%)$ & $6(10.2 \%)$ & $4(6.8 \%)$ & $4(6.8 \%)$ \\
\hline Books to help with your study & $12(23.5 \%)$ & $9(17.6 \%)$ & $4(7.8 \%)$ & $8(15.7 \%)$ & $8(15.7 \%)$ & $5(9.8 \%)$ & $2(3.9 \%)$ & $3(5.9 \%)$ \\
\hline Technical reference books or manuals & $4(23.5 \%)$ & $3(17.6 \%)$ & $0(0 \%)$ & $1(5.9 \%)$ & $4(23.5 \%)$ & $2(11.8 \%)$ & $1(5.9 \%)$ & $2(11.8 \%)$ \\
\hline A dictionary & $18(24.3 \%)$ & $9(12.2 \%)$ & $5(6.8 \%)$ & $15(20.3 \%)$ & $10(13.5 \%)$ & $6(8.1 \%)$ & $5(6.8 \%)$ & $6(8.1 \%)$ \\
\hline A dishwasher & $1(7.1 \%)$ & $4(28.6 \%)$ & $3(21.4 \%)$ & $2(14.3 \%)$ & $1(7.1 \%)$ & $1(7.1 \%)$ & $1(7.1 \%)$ & $1(7.1 \%)$ \\
\hline A DVD player & $18(26.9 \%)$ & $11(16.4 \%)$ & $7(10.4 \%)$ & $7(10.4 \%)$ & $8(11.9 \%)$ & $8(11.9 \%)$ & $5(7.5 \%)$ & $3(4.5 \%)$ \\
\hline A guest room & $5(21.7 \%)$ & $4(17.4 \%)$ & $3(13.0 \%)$ & $3(13 \%)$ & $4(17.4 \%)$ & $1(4.3 \%)$ & $2(8.7 \%)$ & $1(4.3 \%)$ \\
\hline A high-speed Internet connection & $5(19.2 \%)$ & $4(15.4 \%)$ & $2(7.7 \%)$ & $5(19.2 \%)$ & $3(11.5 \%)$ & $1(3.8 \%)$ & $3(11.5 \%)$ & $3(11.5 \%)$ \\
\hline A musical instrument & $9(25 \%)$ & $3(8.3 \%)$ & $2(5.6 \%)$ & $8(22.2 \%)$ & $3(8.3 \%)$ & $4(11.1 \%)$ & $4(11.1 \%)$ & $3(8.3 \%)$ \\
\hline
\end{tabular}

\section{E. Effects of Gadgets and Internet Connectivity on Performance}

The hypotheses were set up to test whether gadgets and the internet affect the students' performance in the course. From the data, it was seen that the popular devices among the students were laptops and mobile phones with or without the internet, as shown in Table VI. These significantly affected the performance of the students $\left(x^{2}=59.62, \mathrm{df}=35, \mathrm{p}\right.$-value $=0.006)$. 
TABLE VI. STUDENTS PERFORMANCE WITH GADGETS

\begin{tabular}{|c|c|c|c|c|c|c|c|c|}
\hline \multirow{2}{*}{ Gadgets } & \multicolumn{9}{|c|}{ GPA } & $\boldsymbol{B}$ & $\boldsymbol{B}+$ & $\boldsymbol{A}$ & $\boldsymbol{A}^{+}$ \\
\cline { 2 - 8 } & $\boldsymbol{E}$ & $\boldsymbol{D}$ & $\boldsymbol{C}$ & $\boldsymbol{C}$ & $\boldsymbol{B}$ & & \\
\hline Mobile phone without Internet & $18(26.08 \%)$ & $10(14.49 \%)$ & $8(11.6 \%)$ & $17(24.6 \%)$ & $6(8.7 \%)$ & $4(5.8 \%)$ & $2(2.9 \%)$ & $4(5.8 \%)$ \\
\hline Smartphone with Internet & $16(27.1 \%)$ & $9(15.3 \%)$ & $7(11.9 \%)$ & $4(6.8 \%)$ & $9(15.3 \%)$ & $7(11.9 \%)$ & $4(6.8 \%)$ & $3(5.1 \%)$ \\
\hline Tablet computer & $4(26.7 \%)$ & $1(6.7 \%)$ & $2(13.3 \%)$ & $3(20 \%)$ & $2(13.3 \%)$ & $1(6.7 \%)$ & $1(6.7 \%)$ & $1(6.7 \%)$ \\
\hline Laptop & $23(27.4 \%)$ & $12(14.3 \%)$ & $11(13.1 \%)$ & $13(15.5 \%)$ & $8(9.5 \%)$ & $7(8.3 \%)$ & $4(4.8 \%)$ & $6(7.1 \%)$ \\
\hline PC & $2(15.4 \%)$ & $2(15.4 \%)$ & $0(0 \%)$ & $2(15.4 \%)$ & $3(23.1 \%)$ & $0(0 \%)$ & $4(30.8 \%)$ & $0(0 \%)$ \\
\hline
\end{tabular}

Table VII illustrates that the students mostly access the internet from the university labs and their homes. These did not have any significant association with their performance $\left(x^{2}=28.05, \mathrm{df}=35, \mathrm{p}\right.$-value $\left.=0.795\right)$ in terms of achieving a particular grade. These also did not have any significant association with the pass or fail status of the students $\left(x^{2}=8.116, \mathrm{df}=5, \mathrm{p}\right.$-value $\left.=0.15\right)$.

TABLE VII. STUDENTS INTERNET USAGE

\begin{tabular}{|c|c|c|c|c|c|c|c|c|}
\hline \multirow{2}{*}{ Internet Access } & \multicolumn{8}{|c|}{ GPA } \\
\hline & $E$ & $D$ & $C$ & $C+$ & $B$ & $B+$ & $A$ & $A+$ \\
\hline Internet From Home & $32(29.6 \%)$ & $17(15.7 \%)$ & $11(10.2 \%)$ & $15(13.9 \%)$ & $11(10.2 \%)$ & $9(8.3 \%)$ & $7(6.5 \%)$ & $6(5.6 \%)$ \\
\hline Internet from Internet Cafe & $26(36.1 \%)$ & $11(15.3 \%)$ & $6(8.3 \%)$ & $10(13.9 \%)$ & $5(6.9 \%)$ & $8(11.1 \%)$ & $3(4.2 \%)$ & $3(4.2 \%)$ \\
\hline Internet from University Lab & $40(32.3 \%)$ & $20(16.1 \%)$ & $13(10.5 \%)$ & $17(13.7 \%)$ & $13(10.5 \%)$ & $10(8.1 \%)$ & $6(4.8 \%)$ & $5(4.0 \%)$ \\
\hline Internet from Wireless Network & $37(34.6 \%)$ & $17(15.9 \%)$ & $11(10.3 \%)$ & $14(13.1 \%)$ & $11(10.3 \%)$ & $6(5.6 \%)$ & $5(4.7 \%)$ & $6(5.6 \%)$ \\
\hline Internet from Smart Phone & $28(36.4 \%)$ & $12(15.6 \%)$ & $6(7.8 \%)$ & $9(11.7 \%)$ & $8(10.4 \%)$ & $6(7.8 \%)$ & $5(6.5 \%)$ & $3(3.9 \%)$ \\
\hline
\end{tabular}

\section{DISCUSSION}

The analysis results support the hypothesis that specific household possessions positively impact the students' academic performance.

The crosstabs and chi-square tests reveal that most students prefer living with either parents or relatives; however, this does not in any way affect their performance. This finding does not concur with [2].

Almost two-thirds of the students live nearby (either on campus or just a 15-minutes walk) from the university. It is notable to see that this does not have any significant relationship to their performance. Students' most popular items in their homes that assist them in their studies were a study desk, a computer, and a study room. These items are statistically significant to students' performance in the computing course. As far as gadgets are concerned, students' most popular devices are laptops and mobile phones with or without the internet. These significantly affected the students' performance. Students who owned one of the popular gadgets tend to perform better than those that do not. On internet access, it was also found out that the students use the internet mostly from the university labs, wireless networks and as well as in their homes. These did not have any significant association with their performance in the computing performance.

It is seen that students with most household items have a positive impact on their computing performance. Household items like educational software, internet or high-speed internet connectivity, textbooks, reference books, laptops, and personal computers are highly significant to obtain a passing grade in the computing course. This might be due to the course requirement, where it requires a lot of hands-on programming exercises to understand the programming language taught in the course. Students need educational software on their computing gadgets to perform these hands-on exercises to understand the course materials better. Thus, the results show that those students with these privileges tend to perform better than their counterparts.

The findings show that many researchers have also identified family background as one of the factors influencing the performance of a student in various subjects and areas of endeavours $[2,4,5,6,8,9,17,18,19,28]$. Okioga found similar results in his research. It was found that the higher the socioeconomic background, the easy to afford the basic needs necessary for the academic performance [6]. It also reported that access and affordability of information communication facilities and services, library materials contributed to the student's academic performance. Tomul and Polat [5] findings showed a positive relationship between students' final exam scores and the variables that reflect the socioeconomic structure of the family. Kakumbi et al. found out that students background is a major factor in influencing the student's performance [17].

\section{CONCLUSION}

There has been an increase in research on the relationship between student background and education around the world. However, this was the first of its kind research conducted in the South Pacific where data from a first-year computer programming course were collected on students' backgrounds such as their living status, home possessions, gadgets, and internet access to investigate possible associations between the student background and their performance. It was found out that most students live with parents or relatives or other students, but there is no significant association with their performance in the course. The same can be concluded about how far the students live from the university.

The study's findings show that a student's background is a significant factor in influencing their computing course performance. The study's finding is consistent with earlier studies that concluded that students' background 
characteristics show a strong influence on students' performance.

The limited household items of students who do not perform well may be attributed to students' parents/guardians' limited financial resources. This might be due to their low socioeconomic status, making them unable to purchase and provide other students' resources.

A possible limitation of this study is that fewer samples were used and some variables from PISA were used as indicators for the student background. Therefore, it is likely that this study might have overlooked other important student background variables that are significant and of importance in Fiji and South Pacific. In light of the study's findings and limitations, it is concluded that some of the home possession played a significant role in USP students' performance in the first-year computer programming course. Specifically, owning a study desk, a computer, laptops, mobile phones, and a study room positively correlate with their performance. It is recommended that parents and students should invest in these items if they want to succeed in the first-year programming course. Parents should also monitor the children to use of computers and their related online activities. Measures should also be put in place for students to use the internet for educational and learning purposes.

Parental socioeconomic status has an enormous influence on students' academic achievement in universities. Therefore, parents need to boast their socioeconomic status in order to meet up with their children's needs in university. Parents need to notice the importance of household items that help a student succeed at a university.

\section{REFERENCES}

[1] Deo, S., Sen, D., \& Ismail, M. I. (2014). Teaching Programming at Distance Learning Mode in Fiji: Survey of Two Campus of the University of the South Pacific (USP). SSRN.

[2] Schulz, Wolfram (2005). Measuring the Socioeconomic Background of Students and Its Effect on Achievement on PISA 2000 and PISA 2003. Online Submission.

[3] Economic Co-operation, O., \& OECD. (2013). PISA 2012 results: excellence through equity: giving every student the chance to succeed, volume II.

[4] Sirin, S. R. (2005). Socioeconomic status and academic achievement: A meta-analytic review of research. Review of Educational Research, 75(3), 417-453.

[5] TOMUL, Ekber \& POLAT, G"okhan (2013). The effects of socioeconomic characteristics of students on their academic achievement in higher education. American Journal of Educational Research, 1, 449-455.

[6] Okioga, Charles Kombo (2013). The impact of students socioeconomic background on academic performance in Universities, a case of students in Kisii University College. Am. Int. J. Soc. Sci, 2, 38-46.

[7] Woessmann, Ludger (2004). How equal are educational opportunities? Family background and student achievement in Europe and the US.

[8] Abdu-Raheem, B O (2015). Parents' Socioeconomic Status as Predictor of Secondary School Students' Academic Performance in Ekiti State, Nigeria. Journal of Education and Practice, 6, 123-128.

[9] Caldas, Stephen J \& Bankston, Carl (1997). Effect of school population socioeconomic status on individual academic achievement. The Journal of Educational Research, 90, 269-277.
[10] Kan, Kamhon \& Tsai, Wei-Der (2005). Parenting practices and children's education outcomes. Economics of Education Review, 24, $29-43$.

[11] McMillan, Julie \& Western, John (2000). Measurement of the socioeconomic status of Australian higher education students. Higher Education, 39, 223-247.

[12] Finnie, R., Lascelles, E., \& Sweetman, A. (2005). Who goes? The direct and indirect effects of family background on access to postsecondary education.

[13] OCDE. (2004). Learning for tomorrow's world: First results from PISA 2003. OCDE Paris.

[14] Morgan, P. L., Farkas, G., Hillemeier, M. M., \& MacZuga, S. (2009). Risk factors for learning-related behavior problems at 24 months of age: Population-based estimates. Journal of Abnormal Child Psychology, 37(3), 401-413.

[15] Aikens, N. L., \& Barbarin, O. (2008). Socioeconomic differences in reading trajectories: The contribution of family, neighborhood, and school contexts. Journal of Educational Psychology, 100(2), 235. article.

[16] Marzano, R. J. (2004). Building background knowledge for academic achievement: Research on what works in schools.

[17] Kakumbi, Z., Samuel, E. B., \& Mulendema, P. J. (2016). Pupil Home Background Characteristics and Academic Performance in Senior Secondary Schools: A Case Study of Selected Secondary Schools in Kitwe District, Zambia. Journal of Education and Practice, 7(22), 1925.

[18] Bowers, A. J., \& Urick, A. (2011). Does high school facility quality affect student achievement? A two-level hierarchical linear model. Journal of Education Finance, 37(1), 72-94.

[19] Baker, D., Goesling, G., \& LeTendre, G. (2002). Socioeconomic status, school quality, and national economic development: A cross-national analysis of the "Heyneman - Loxley Effect" on mathematics and science achievement. Comparative Education Reviews, 46, 291 - 312.

[20] Organisation for Economic Cooperation and Development. (2017). PISA 2015 results: excellence and equity in education. OECD.

[21] Mushtaq, I., \& Khan, S. N. (2012). Factors Affecting Students Academic Performance. Global journal of management and business research, 12(9), 1-7.

[22] Corney, M., Teague, D., Thomas, R.N. (2010). Engaging students in programming. In: Twelfth Australasian Conference on Computing Education - Volume 103. 63-72.

[23] Hu, M., Winikoff, M., Cranefield, S. (n.d.). Teaching Novice Programming using goals and plans in a visual notation. In: the Fourteenth Australasian Computing Education Conference (ACE2012). Melbourne, Australia.

[24] Yinusa, M. A., \& Basil, A. O. (2008). Socioeconomic factors influencing students academic performance in Nigeria: Some explanation from a local survey. Pakistan Journal of Social Sciences, 5(4), 319-323.

[25] Farooq, M. S., Chaudhry, A. H., Shafiq, M., \& Berhanu, G. (2011). Factors affecting students' quality of academic performance: a case of secondary school level. Journal of quality and technology management, 7(2), 1-14.

[26] Nikula, U., Gotel, O., \& Kasurinen, J. (2011). A motivation guided holistic rehabilitation of the first programming course. ACM Transactions on Computing Education (TOCE), 11(4), 1-38.

[27] Naseem, M., Chaudhary, K., Sharma, B., \& Lal, A. G. (2019). Using Ensemble Decision Tree Model to Predict Student Dropout in Computing Science. In 2019 IEEE Asia-Pacific Conference on Computer Science and Data Engineering (CSDE), 1-8.

[28] Prasad, A., \& Chaudhary, K. (2020). Interactive Animation and Affective Teaching and Learning in Programming Courses. In Advances in Computer, Communication and Computational Sciences, 613-623. 